\title{
Direct-Seeded Rice in Nepal
}

Razan Malla ${ }^{1 *}$

${ }^{1}$ Soil Scientist, Soil Science Division, Khumaltar Lalitpur, Nepal

Article History

Received: 18.01 .2021

Accepted: 21.03 .2021

Published: 26.03.2021

Journal homepage: http://www.easpublisher.com

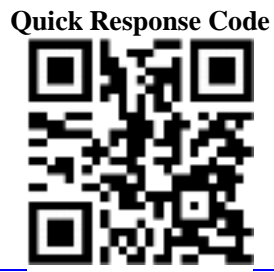

Abstract: To over half the world's population, rice is the primary staple food. In recent years, there has been a shift from transplanted rice to direct-seeded rice cultivation mainly driven by seasonal scarcity of agricultural labor, increasing water scarcity, and high cost of production. Labor constraints mean sowing and transplanting are often delayed, resulting in yield losses. It is cost and time intensive for farmers. It causes adverse effects to soil and environment. Because of the low input demand, direct-seeded rice (DSR) has gained a lot of attention. Direct seeded rice refers to the process of developing seed crops from field seeds instead of transplanting seedlings. Three methods of direct seeding are known, namely: dry-DSR, wet-DSR and water seeding. Precise land grading, good crop establishment, accurate water management, weed management, and nutrient management are the most important prerequisites for successful direct-seed rice crop. There are no varieties to date specifically targeted for DSR but many of the inbred varieties and hybrids bred for puddled transplanted are found to be suitable. Direct seeding follows the aerobic cultivation of paddy, so the nutrient dynamics are altered. Several key nutrients like N, P, S, Zn, and Fe are likely to be a constraint. The infestation of weeds can cause significant loss of DSR yield.

Keywords: direct-seeded Rice, nutrient, water, weed management, resource conservation.

Copyright (C) 2021 The Author(s): This is an open-access article distributed under the terms of the Creative Commons Attribution 4.0 International License (CC BY-NC 4.0) which permits unrestricted use, distribution, and reproduction in any medium for non-commercial use provided the original author and source are credited.

\section{INTRODUCTION}

Rice (Oryza sativa L.) is the staple food for almost 3 billion people that is about $50 \%$ of the world's population. At least 114 countries grow rice. It is projected that by 2025 , the world's farmers will need to grow around 60 per cent more rice than they are currently producing to meet the food demands of the world's expected population at the time [1]. Throughout Asia ninety percent of all rice is cultivated and eaten.

In Nepal, rice contributes about $21 \%$ to the agriculture gross domestic product. The national average yield of rice $\left(3.76 \mathrm{tha}^{-1}\right)$ is far below the Asian average [2]. More than $70 \%$ of the rice growing areas in Nepal fall in terai region followed by hills and mountains. It is estimated that more than 90 percent of rice is grown in puddled soil in Nepal [3]. Traditional transplanted puddled rice is valuable for resource use efficiency. It conserves water, increases nutrient availability while suppressing the weeds [4]. Puddling over time degrades the soil; soil aggregates are dissolved; permeability is reduced and hard pans of soil formed at shallow depths [5]. The need for ponded water also delays the transplantation of rice for 1 to 3 weeks [6].

There has been a change in recent years from transplanted rice to direct-seeded rice cultivation in many Southeast Asian countries [7]. This shift was mainly driven by the increasing water scarcity, shortage of labor and high cost of production. Much effort and new ideas are emerging to improve rice production and productivity [8]. One of such emerging concepts is, Direct Seeded Rice.

Table-1: Grain yield comparisons between conventional puddled transplanting and various alternative tillage and crop establishment methods in Nepal

\begin{tabular}{|l|l|l|l|l|}
\hline SN & Tillage and CE methods & No. of studies & Adjusted mean yield $\left(\mathbf{t ~ h a}^{-1}\right)$ & p-value \\
\hline 1 & CT-TPR & 14 & 4.80 & - \\
\hline 2 & $\begin{array}{l}\text { CT-wet seeding } \\
\text { (CT-wet-BCR, CT-wet-DSR) }\end{array}$ & 6 & 5.00 & NS \\
\hline 3 & CT/RT-dry-DSR & 15 & 4.80 & NS \\
\hline 4 & Bed-dry DSR & 3 & 4.55 & NS \\
\hline
\end{tabular}

Source: Kumar and Ladha, 2011. 


\section{Methodology}

Systematic reviews of different published and unpublished papers, journal and books were done and their conclusions were drawn and summarized the evidence by use of explicit methodology. The results of the different articles were summarized in this paper.

\section{ReSUlts AND Discussions \\ Direct seeded rice}

Direct seeded rice refers to the process of developing seed crops from field seeds instead of transplanting seedlings [9]. Direct seeding eliminates three main basic operations, namely puddling, transplantation and the management of standing water. In addition to higher economic returns, DSR crops are quicker and easier to grow, have shorter durations, less labor intensive, less water usage [10], fewer methane emissions and conducive to mechanization [11]. Some reports indicate DSR yields close to or even higher yields with good management practices. DSR yields are often lower than rice transplanted, mainly because of poor crop population, high panicle sterility and higher weed infestations [12]. High infestation of weeds and nutrient deficiencies are essential constraints for wider adoption of DSR.

Direct seeding was the most common prior to the 1950s but was slowly replaced by puddled transplantation [13]. Three methods of direct seeding are known, namely: dry-DSR, wet-DSR and water seeding. Wet-DSR is common where there is a shortage of labor. It is practiced in Malaysia, Vietnam, Thailand, and Srilanka [7]. Water seeding is done in lands with a history of weed problems. Dry-DSR is the most popular method among all amidst the looming water and labor shortages and changing climatic scenario. It is popular in the upland rainfed ecosystem. Dry seeding in rainfed lowland, upland, and flood-prone areas in Asia is extensively practiced, while wet seeding in irrigated areas remains common practice $[14,15]$. Direct seeding in Nepal is done in dry fields on uplands. This practice is more prevalent in the hills in uplands. Direct seeding is also done in western Nepal in lowlands where labor is short and the eastern lowlands where water gets stagnated during monsoon.

Table-2: Classification of direct-seeded rice (DSR) system.

\begin{tabular}{|l|l|l|l|}
\hline \multicolumn{1}{|c|}{$\begin{array}{c}\text { System of } \\
\text { direct seeding }\end{array}$} & \multicolumn{1}{|c|}{$\begin{array}{c}\text { Seed bed condition and } \\
\text { environment }\end{array}$} & \multicolumn{1}{c|}{ Sowing method } & \multicolumn{1}{c|}{ Suitable ecology } \\
\hline $\begin{array}{l}\text { Direct seeding } \\
\text { in dry bed }\end{array}$ & $\begin{array}{l}\text { Dry seeds are sown in dry and } \\
\text { mostly aerobic soil }\end{array}$ & $\begin{array}{l}\text { Broadcasting, Drilling or sowing } \\
\text { in rows at depth of 2-3 cm }\end{array}$ & $\begin{array}{l}\text { Mainly in rain fed area, some in irrigated } \\
\text { areas with precise water control }\end{array}$ \\
\hline $\begin{array}{l}\text { Direct seeding } \\
\text { in wet bed }\end{array}$ & $\begin{array}{l}\text { Pre germinated seeds sown in } \\
\text { puddled soil, may be aerobic } \\
\text { or anaerobic }\end{array}$ & Various & $\begin{array}{l}\text { Mostly in favorable rainfed lowlands and } \\
\text { irrigated areas with good drainage } \\
\text { facility }\end{array}$ \\
\hline $\begin{array}{l}\text { Direct seeding } \\
\text { in Standing } \\
\text { Water }\end{array}$ & $\begin{array}{l}\text { Dry or Pre germinated seeds } \\
\text { sown mostly in anaerobic } \\
\text { condition in standing water }\end{array}$ & $\begin{array}{l}\text { Broadcasting on standing water of } \\
5-10 \mathrm{~cm}\end{array}$ & $\begin{array}{l}\text { In areas with red rice or weedy rice } \\
\text { problem and in irrigated lowland areas } \\
\text { with good land leveling }\end{array}$ \\
\hline
\end{tabular}

Source: Joshi et al., [41].

\section{Land preparation}

DSR can be achieved whether through conventional tillage or through conservation tillage. The decision as to whether or not the soil should be cultivated depends on leveling requirements, the availability of appropriate equipment, weeding and crop rotation. For conventional till the field should be cultivated to a depth of $5-10 \mathrm{~cm}$ and pulverized to maintain good soil tilth. Any existing weeds are killed with a non-selective herbicide. Care should be given to only use herbicides when the weeds are in active production stage.

Proper land leveling is an important prerequisite for DSR. Laser leveling is a good option but may not be feasible for all. Use of locally available equipment's like raiser and planking can be equally effective proper leveling of land is a significant precondition for DSR. Laser leveling is a decent choice, but it is difficult for anyone to accomplish. The use of local equipment can be equally efficient, such as raiser and planks. If farmers do not have access to levelling equipment's, measuring water depth at various locations when the field is flooded can give a fair idea of field's levelness. An even irrigation field allows for a uniform crop base and improves the weed control and efficiency of fertilizer use [16]. Land leveling saves 2025 percent of irrigation water [17]. DSR performance is associated to land leveling accuracy. Existing weeds should be burned with herbicidal products such as paraquat (@0.5 kg a.i. ha-1 and glyphosates@ $1.0 \mathrm{~kg}$ a.i. ha-1) for zero tilled direct seeded rice [18]. Summer ploughings are desirable in areas with heavy weed infestations.

\section{Time of sowing}

If irrigation is available, sowing of the crop is best 10-15 days before the monsoon starts [19, 20]. Optimal planting time means that the total yield is increased by up to $30 \%$ [21]. The ideal period for dry rice in the mid-hills is in the middle of May while the best period in the foothills is from late May to early June. The best time in the Terai is between the end of May and the beginning of June. The risk of heavy rain shortly after planting is higher, which will affect the establishment, particularly for clayey soil. The monsoon rain normally starts later in the western and central part of Terai and can be seeded during the first week of 
June. However, the earlier the crop is sown, the greater the need for irrigation. Direct seeding in the lowlands of eastern Nepal is done in standing water from the monsoon which continues to do so even after harvest till January and February. So seeding is done in AprilMay in residual soil moisture. The rice germinates and becomes $10-15 \mathrm{~cm}$. tall at the break of monsoon. Photoperiod-sensitive varieties of rice are grown there.
In the far west, direct-seeding is done after one or two rainfalls, when this soil has sufficient moisture to germinate the seed. In this condition, rice and weeds germinate together. So, weeds are a problem. When rice plants are $20-25 \mathrm{~cm}$. tall, they are plowed with a thin plow. By this action, the rice population becomes thin but weeds are controlled to some extent.

Table-3: Effect of sowing dates on grain yield and yield components at Parwanipur, Nepal

\begin{tabular}{|l|l|l|l|l|l|l|l|l|}
\hline \multirow{2}{*}{ Sowing date } & \multicolumn{2}{|l|}{ Tillers/m2 } & \multicolumn{2}{l|}{ Grains/panicle } & \multicolumn{1}{l|}{ 1000-grain wt. (g.) } & \multicolumn{2}{l|}{ Grain yield (kg/ha) } \\
\cline { 2 - 9 } & $\mathbf{1 9 9 8 / 9 9}$ & $\mathbf{1 9 9 9 / 0 0}$ & $\mathbf{1 9 9 8 / 9 9}$ & $\mathbf{1 9 9 9 / 0 0}$ & $\mathbf{1 9 9 8 / 9 9}$ & $\mathbf{1 9 9 9 / 0 0}$ & $\mathbf{1 9 9 8 / 9 9}$ & $\mathbf{1 9 9 9 / 0 0}$ \\
\hline 15 June & 240 & 316 & 100 & 99 & 22.2 & 24.2 & 4357 & 4497 \\
\hline 29 June & 186 & 277 & 105 & 81 & 21.9 & 23.9 & 4357 & 4282 \\
\hline 14 July & 166 & 258 & 92 & 86 & 21.1 & 23.9 & 2972 & 4146 \\
\hline 29 July & 169 & 199 & 71 & 65 & 20.7 & 23.7 & 2154 & 2266 \\
\hline
\end{tabular}

Source: Shah and Bhurer, [42].

It was also reported that the reason for decline grain yield might be due to delayed panicle formation and grain filling in the season where temperature and solar radiation are less [22]. The earlier sown crop benefited from better sunshine and appropriate temperature that resulted into a more vigorous and extensive root system leading to high yields in early seeding.

\section{Selection of varieties}

Varieties of faster growth, enhanced early strength for weed competitiveness [23] and an effective root system are sufficient for DSR to tap the moisture of the soil during dry periods. Early-heading rice varieties with a higher drought tolerance are better suited for the purpose of dry-seeded rice. The resistance to lodgings is also a beneficial attribute to direct seeding [24]. The high yield varieties have a higher percentage of germination and are more suitable. Local varieties are tall and lodging susceptible, so they are not suitable for direct-seeding. Broadcasting seeds on soil results in more lodging even with high yielding varieties.

Table-4: Effect of varieties on grain yield and yield components regardless of sowing dates

\begin{tabular}{|c|c|c|c|c|c|c|c|c|}
\hline Varieties & \multicolumn{3}{|c}{ Tillers/m2 } & \multicolumn{3}{c|}{ Grains/panicle } & \multicolumn{1}{c|}{ 1000 grain wt. (gm.) } & \multicolumn{2}{c|}{ Grain Yield (kg/ha) } \\
\hline & $1998 / 99$ & $1999 / 00$ & $1998 / 99$ & $1999 / 00$ & $1998 / 99$ & $1999 / 00$ & $1998 / 99$ & $1999 / 00$ \\
\hline Chaite 2 & 172 & 259 & 106 & 91 & 20.6 & 24.0 & 3366 & 4197 \\
\hline Radha 4 & 197 & 245 & 86 & 80 & 24.8 & 27.8 & 3757 & 3769 \\
\hline Chaite 6 & 213 & 302 & 78 & 72 & 20.9 & 22.8 & 3154 & 3777 \\
\hline Radha 11 & 180 & 245 & 97 & 87 & 19.6 & 21.1 & 2953 & 3447 \\
\hline
\end{tabular}

Source: Shah and Bhurer, 2005.

Table-5: Suitable cultivars for DSR in the Terai and mid-hills of Nepal

\begin{tabular}{|c|c|c|c|}
\hline Variety & Duration (Days) & Yield (kg/ha) & Region / situation \\
\hline Hardinath-1 & $110-115$ & 5.0 & Terai and Inner Terai \\
\hline Tarahara-1 & 115 & 4.2 & Eastern and central Terai \\
\hline Radha-4 & $120-25$ & 3.2 & Foothills and Terai region \\
\hline Sukha-1 & 125 & $2.5-3.6$ & Terai and inner Terai, river basin \\
\hline Sukha-2 & 125 & $3.3-3.5$ & Terai and inner Terai, river basin \\
\hline Sukha-3 & 125 & $3.2-4.2$ & Chitwan \\
\hline Ram Dhan & $138-148$ & 4.9 & Terai and inner Terai \\
\hline Sabitri & $140-145$ & 4.0 & Officially not released but popular, Terai, inner Terai, irrigated and \\
\hline Samba-Sub-1 & $145-150$ & 4.0 & rainfed lowland \\
\hline Sona Masuli & $150-155$ & 4.5 & Terai (Officially not released but cover a large area in Central Terai) \\
\hline Khumal-4 & 144 & 6.3 & Mid hills \\
\hline Khumal-8 & 158 & 9.8 & Mid hills \\
\hline Khumal-10 & 145 & 4.5 & Terai, inner Terai, irrigated and rainfed lowland \\
\hline Gorakhnath & $120-125$ & $6-7$ & Terai, inner Terai, irrigated and rainfed lowland \\
\hline Arize 6444 & $135-140$ & $7-8$ & Terai, inner Terai, irrigated and rainfed lowland \\
\hline Bioseed -786 & $120-125$ & $7-8$ & Terai, inner Terai, irrigated and rainfed lowland \\
\hline RH-245 & $120-125$ & $5-6$ & Terai, inner Terai, irrigated and rainfed lowland \\
\hline Loknath-505 & $120-125$ & $5-6$ & Terai, inner Terai, irrigated and rainfed lowland \\
\hline Raja & $120-125$ & $5-6$ & She \\
\hline
\end{tabular}




\section{Seed priming}

Seed priming is an effective approach to address the drought stress as DSR is sown at a shallow depth $(<2 \mathrm{~cm})$ in advance of the monsoon rains [25]. Priming accelerates crop emergence and establishment. Usually, the rice seed is soaked for 24 hours and incubated for 48 hours before seeding. In the first place, the seeds are stored in a gunny sack overnight. The seed should be seeded shortly thereafter. Seeds can also be soaked in fungicide and antibiotics solution. Priming with imidacloprid increased the panicle numbers and filled grains per panicle [18]. Seed priming also decreased seeding requirements, but was counterproductive when the soil was near or at saturation [18].

\section{Seed rates and seeding depth}

High seed rates are used mostly in areas where the seed is broadcast to suppress weeds or when water seeded [26]. About $80-100 \mathrm{~kg} / \mathrm{h}$ a seed rate is used. The seed rate is the same as for upland rice but double the rate of transplanted rice. In very dense populations, higher sterility and fewer grains per panicle are common [27]. Dense populations of plants with high seed levels may also establish conditions for disease, such as sheath blight $[28,29]$ and insects causing plants to lodge easily [30]. Seeding depth should not be kept more than $3 \mathrm{~cm}$ for desired level of crop stand because of rapid drying of upper soil moisture.

\section{Planting machinery}

In order to ensure accurate and efficient seeding, the rice should be drilled with a multi-crop planter equipped with seed metering systems with inclined plate and inverted T-type tynes. Seed drills with inverted-T tynes are suitable for seeding into both tilled and non-tilled soil. It is possible to do better crop establishment with lower seed rate and more reliable plant-to-plant spacing with these precise seed metering planters [31]. Multi-crop planter can be used for seeding where there are few residues to work with. But in case of bulkier crop residues Turbo Happy Seeder should be used. In Nepal, 2-wheel tractor seed-cum fertilizer drills may be used for DSR on a small farm holding in the foothills, inner Terai and in the Terai zone. The depth of seeding needs to be adjusted to achieve a seeding depth of $1-2 \mathrm{~cm}$.

\section{Nutrient Management}

Direct seeding follows the aerobic cultivation of paddy, so the nutrient dynamics are altered [32]. Several key nutrients like N, P, S, Zn, and Fe are likely to be a constraint [33]. Besides, $\mathrm{N}$ losses in DSR are very high. Fertilizer recommendations for DSR are similar to that of transplanted rice except for a higher dose of $\mathrm{N}$ should be used to balance out the higher $\mathrm{N}$ losses [21]. A 100-120 kg N/ha in 3-4 splits and P2O5 at $40 \mathrm{~kg} / \mathrm{ha}, \mathrm{K} 2 \mathrm{O}$ at $30 \mathrm{~kg} / \mathrm{ha}$, and $\mathrm{ZnSO} 4$ at $25 \mathrm{~kg} / \mathrm{ha}$ (in Terai) is recommended. A full dose of $\mathrm{P}$ and $\mathrm{K}$ and $1 / 3 \mathrm{~N}$ as basal should be given at the moment of sowing. The remainder of the $2 / 3$ dose of $N$ would be better suited for tillering and panicle initiation [20]. IRRI uses a leaf color chart (LCC) to manage $\mathrm{N}$ [22]. Use of slow-release or controlled-release $\mathrm{N}$ fertilizers offers advantage due to their delayed-release thus reducing losses, labor cost and increasing efficiency [34]. But due to its heavy price, its use is limited. Zinc deficiency is a common problem in DSR [35]. Basal application of zinc to the soil has been found to be the safest way to prevent its deficiency. When $\mathrm{Zn}$ is not added during seeding, it can be added 30 days after sowing (DAS) and at panicle initiation as a foliar spray ( $0.5 \%$ zinc sulfate and $1.0 \%$ urea).

\section{Water management}

In Asia, the agricultural water share decreased from $98 \%$ in 1900 to $80 \%$ in 2000 and is expected to decrease further to $72 \%$ by 2020 . Precise management of water is critical in direct-seeded rice, particularly during crop emergence phase (first 7-15 days) [36]. Water management should be such that the field can be irrigated and drained whenever needed. Initially, $3 \mathrm{~cm}$, of water is needed. Water should not be excessive otherwise; tiller numbers will be reduced. Frequent irrigation is necessary to keep the soil moist in the root zone, particularly on lighter soils, which may require irrigation every few days. The topsoil should be kept near saturation during the active tillering process and the moving to the grain-filling point. The presence of hairline cracks on the soil surface is a general indicator for the need to irrigate clayey soils. 


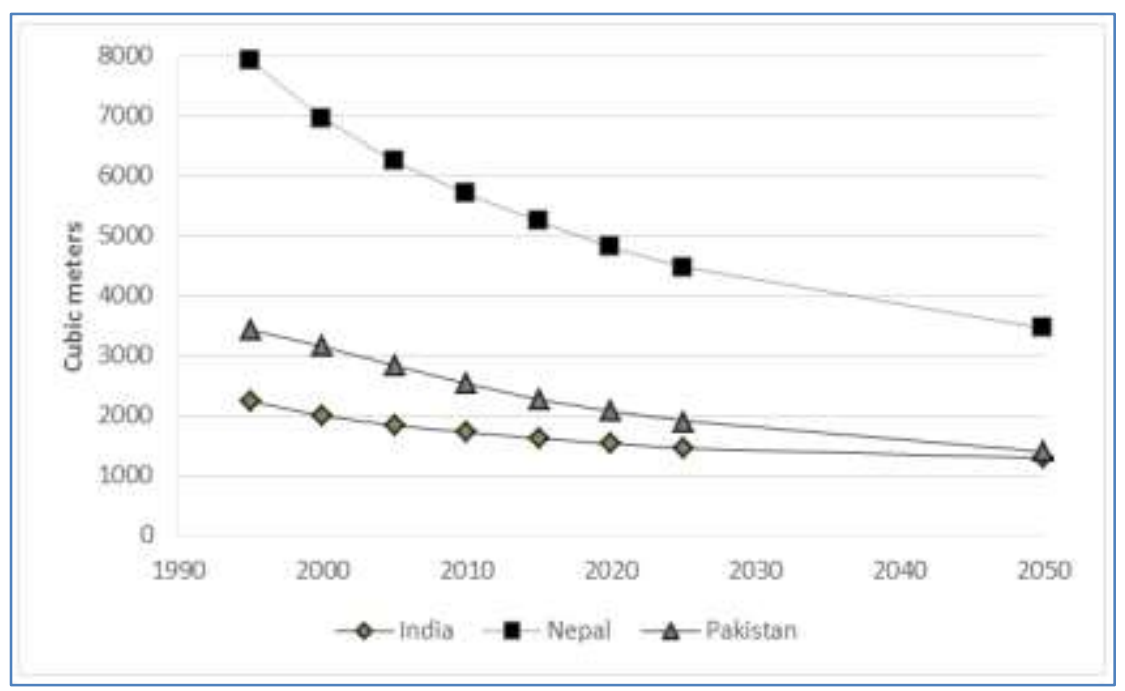

Fig-1: Per capita water availability in rice growing countries (1950-2050) *2010-2050 projections based on population growth

Source: Modified from Gardner-Outlaw and Engelman [37]

\section{Weed Management}

Weed management is usually the major constraint for the successful production of DSR [19]. The DSR fields are infested with weeds of greater diversity [38]. Weed control is more costly and problematic because there is no water to reduce the development of weeds and rice and weeds continue to germinate together [39]. The germinating seeds remain on top of the soil, so there are more problems with birds, rats, snails, and weeds. In DSR areas, weedy rice has become a significant threat. It is highly competitive and causes major losses in rice yields [9]. FAO recommends a systematic approach integrating prevention, cultural and chemical methods suitable to effectively and sustainably manage weeds in Dry-DSR $[40,43]$.

Stale seedbed technique reduces weed emergence as well as the soil weed seed bank [13]. This technique is highly desirable in fields with long term weed problems. Weeds are encouraged to germinate with irrigation before being killed. When the soil can be seeded, a non-selective herbicide can be used to kill the weeds and the crop should be planted without tillage. If the soil is dry, irrigation should be given before herbicide application. The retention of $15-20 \mathrm{~cm}$ of residues of the previous crop of wheat in zero tilledDSR decreases DSR weeds and improves soil quality. Seeding rice and sesbania together and then killing sesbania with 2, 4-D approximately 25-30 DAS will reduce the weed population by almost half without any adverse effect on rice production [20].

A wide range of herbicides is available for controlling weeds. Preplant herbicides like Glyphosate (1.0 kg a.i. ha $^{-1}$ or $1 \%$ by volume) and paraquat $(0.5 \mathrm{~kg}$ a.i. $\mathrm{ha}^{-1}$ or $0.5 \%$ by volume) are recommended. Pendimethalin $\left(1.0 \mathrm{~kg}\right.$ a.i. ha $\left.{ }^{-1}\right)$, oxadiargyl $(0.09 \mathrm{~kg}$ a.i. $\left.\mathrm{ha}^{-1}\right)$, and pyrazosulfuron $\left(0.02 \mathrm{~kg} \mathrm{ha}^{-1}\right)$ have also been reported to be effective as pre-emergence herbicides for DSR [18]. Postemergence application (15-25 days after sowing) of bispyribac sodium $25 \mathrm{~g}$ a.i. $\mathrm{ha}^{-1}$ was found very effective on most grasses. Bispyribac works well in saturated soil conditions $[20,21]$.

Table-6: Common weeds of DSR in Nepal

\begin{tabular}{|l|l|l|}
\hline Grasses & Broad Leaf Weed & Sedges \\
\hline Echinochloa crusgalli & Eclipta sps. & Cyperus rotundus \\
\hline Echinochloa colona & Caesulia axillaries & Cypeus difformis \\
\hline Leptochloa alba & Ageratum sps. & Cyperus iria \\
\hline Eragrostis tenella & Commelina sp. & Fimbristylis sps \\
\hline Paspalum distichum & Amaranthus spinosus & \\
\hline Digitaria ciliaris & Galinsoga ciliata & \\
\hline Cyanodon dactylon & Alternanthera philoxeroides & \\
\hline Panicumm dichotomiflorum & & \\
\hline Eleusine indica & & \\
\hline
\end{tabular}

\section{CONCLUSION}

Increased crop productivity must be achieved by increasing the efficiency of inputs at a lower cost and by saving natural resources. DSR is one way to achieve it. DSR is being practiced with various tillage/land preparation and crop establishment modifications that are used to meet site-specific 
requirements but have not gained popularity, although several research studies indicate its advantages over transplanted rice. DSR with effective management practices has the ability to achieve yields that are marginally lower or equal to that of TPR, which appears to be a feasible alternative to addressing labor and water shortages. Using this process, equivalent output can be obtained if weed and water control is done properly. A great deal needs to be done on nutrient dynamics in soils under DSR. Achieving appropriate land levelling is key to satisfactory crop establishment, water management and increasing productivity. A sitespecific package of production technologies for different rice production systems needs to be developed in different rice production zones.

\section{REFERENCES}

1. Fageria, N.K. (2007). Yield physiology of rice. Journal of Plant Nutrition, 30:843-879.

2. MoALD. (2019). Statistical information on Nepalese Agriculture. Planning and Development cooperation coordination division, Statistics and analysis section, Singh Darbar, Kathmandu.

3. Upadhyaya, H.K. (1996). Rice research in Nepal: current state and future priorities. In: Evenson, R.E., (Eds.), Rice Research in Asia: Progress and Priorities. CAB International, Wallingford, 193216.

4. Singh, S., Sharma, S. N., \& Prasad, R. (2001). The effect of seeding and tillage methods on productivity of rice-wheat cropping system. Soil and Tillage Research, 61(3-4), 125-131.

5. Sharma, P. K., Ladha, J. K., \& Bhushan, L. (2003). Soil physical effects of puddling in rice-wheat cropping systems. Improving the Productivity and Sustainability of Rice-Wheat Systems: Issues and Impacts, 65, 97-113.

6. Ladha, J. K., Kumar, V., Alam, M. M., Sharma, S., Gathala, M., Chandna, P., ... \& Balasubramanian, V. (2009). Integrating crop and resource management technologies for enhanced productivity, profitability, and sustainability of the rice-wheat system in South Asia. Integrated crop and resource management in the rice-wheat system of South Asia, 69-108.

7. Pandey, S. (2002). Direct seeding: research strategies and opportunities. Int. Rice Res. Inst..

8. Uprety, R. (2006). SRI takes root in Nepal. LEISALEUSDEN-, 22(4), 25.

9. Farooq, M., Siddique, K. H., Rehman, H., Aziz, T., Lee, D. J., \& Wahid, A. (2011). Rice direct seeding: experiences, challenges and opportunities. Soil and Tillage Research, 111(2), 87-98.

10. Bhushan, L., Ladha, J. K., Gupta, R. K., Singh, S., Tirol-Padre, A., Saharawat, Y. S., ... \& Pathak, H. (2007). Saving of water and labor in a rice-wheat system with no-tillage and direct seeding technologies. Agronomy Journal,99(5), 12881296.

11. Wassmann, R., Neue, H. U., Ladha, J. K., \& Aulakh, M. S. (2004). Mitigating greenhouse gas emissions from rice-wheat cropping systems in Asia. In Tropical Agriculture in TransitionOpportunities for Mitigating Greenhouse Gas Emissions? (pp. 65-90). Springer, Dordrecht.

12. Singh, Y., Singh, G., Johnson, D., \& Mortimer, M. (2005). Changing from transplanted rice to direct seeding in the rice-wheat cropping system in India. Rice Is Life: Scientific Perspectives for the 21st Century"(K. Toriyama, KL Heong, and B. Hardy, Eds.), 198-201.

13. Rao, A. N., Johnson, D. E., Sivaprasad, B., Ladha, J. K., \& Mortimer, A. M. (2007). Weed management in direct-seeded rice. Advances in Agronomy, 93, 153-255.

14. Azmi, M., Chin, D. V., Vongsaroj, P., \& Johnson, D. E. (2005). Emerging issues in weed management of direct-seeded rice in Malaysia, Vietnam, and Thailand.Rice is life: Scientific perspectives for the 21st century, 196-198.

15. de Dios, J. L., Javier, E. F., Malabayabas, M. D., Casimero, M. C., \& Espiritu, A. J. (2005). An overview on direct seeding for rice crop establishment in the Philippines. Rice is Life: Scientific Perspectives for the 21st Century. International Rice Research Institute Los Banos, Philippines, and Japan International Research Centre for Agricultural Sciences, Tsukuba, Japan, 189-193.

16. Jat, M. L., Chandna, P., Gupta, R., Sharma, S. K., \& Gill, M. A. (2006). Laser land leveling: A precursor technology for resource conservation. Rice-Wheat consortium technical bulletin series, 7, 48 .

17. Rickman, J. F. (2002). Manual for laser land leveling, Rice-wheat consortium technical Bulletin series 5. New Delhi-110, 12, 24.

18. Gopal, R., Jat, R. K., Kumar, V., Alam, M. M., Jat, M. L., Mazid, M. A., ... \& Gupta, R. (2010). Direct dry seeded rice production technology and weed management in rice based systems.

19. Singh, S., Chhokar, R. S., Gopal, R., Ladha, J. K., Gupta, R. K., Kumar, V., \& Singh, M. (2009). Integrated weed management: a key to success for direct-seeded rice in the Indo-Gangetic plains. Integrated Crop and Resource Management in the Rice-Wheat System of South Asia. Los Banos, Philippines: International Rice Research Institute, 261-278.

20. Kamboj, B. R., Kumar, A., Bishnoi, D. K., Singla, K., Kumar, V., Jat, M. L., ... \& Bhatia, R. (2012). Direct seeded rice technology in western IndoGangetic Plains of India: CSISA experiences.

21. Kumar, V., \& Ladha, J. K. (2011). Direct seeding of rice: recent developments and future research needs. Advances in agronomy, 111, 297-413. 
22. IRRI. (2010). Site-specific nutrient management, www.irri.org/irrc/ssnm. Accessed 30 April 2010.

23. Zhao, D. L., Atlin, G. N., Bastiaans, L., \& Spiertz, J. H. J. (2006). Cultivar weed-competitiveness in aerobic rice: Heritability, correlated traits, and the potential for indirect selection in weed-free environments. Crop Science, 46(1), 372-380.

24. Mackill, D. J., Coffman, W. R., \& Garrity, D. P. (1996). Rainfed Lowland Rice Improvement International Rice Research Institute. Los Banos, Philippines, 242.

25. Farooq, M., Barsa, S. M., \& Wahid, A. (2006). Priming of field-sown rice seed enhances germination, seedling establishment, allometry and yield. Plant growth regulation, 49(2), 285-294.

26. Moody, K. (1977). Weed control in multiple cropping. In Symposium on cropping systems research and development for the Asian rice farmer (pp. 281-294). IRRI.

27. Kabir, M. H., Saha, A., Mollah, I. U., Kabir, M. S., \& Rahman, F. (2008). Effect of crop establishment methods and weed management practices on the productivity of boro rice in lowland ecosystem. Int. J. Biol. Res, 5, 42-51.

28. Guzman Garcia, P., \& Nieto Illidge, L. (1992). Nuevas densidades y fertilizacion para disminuir Rhizoctonia solani. Arroz, 41, 10-14.

29. Mithrasena, Y. J. P. K., \& Adikari, W. P. (1986). Effect of density on sheath blight (ShB) incidence. Int Rice Res Notes, 11, 20-21.

30. Islam, M. F., Sarkar, M. A. R., Islam, M. S., Parveen, S., \& Hossain, M. S. (2008). Effects of crop establishment methods on root and shoot growth, lodging behavior of Aus rice. Int J Biol Res, 5, 60-64.

31. Gupta, R. K., Ladha, J. K., Singh, S., Singh, R., Jat, M. L., Saharawat, Y., ... \& Malik, R. K. (2006). Production technology for direct seeded rice. Rice Wheat Consortium Technical Bulletin, 8, 16.

32. Farooq, M., Basra, S. M., Ahmad, N., \& Murtaza, G. (2009). Enhancing the performance of transplanted coarse rice by seed priming. Paddy and Water Environment, 7(1), 55-63.

33. Ponnamperuma, F. N. (1972). The chemistry of submerged soils. In Advances in agronomy (Vol. 24, pp. 29-96). Academic Press.
34. Shoji, S., Delgado, J., Mosier, A., \& Miura, Y. (2001). Use of controlled release fertilizers and nitrification inhibitors to increase nitrogen use efficiency and to conserve air andwater quality. Communications in Soil Science and Plant Analysis, 32(7-8), 1051-1070.

35. Kirk, G. J. D., \& Bajita, J. B. (1995). Root-induced iron oxidation, $\mathrm{pH}$ changes and zinc solubilization in the rhizosphere of lowland rice. New Phytologist, 131(1), 129-137.

36. Kumar, V., Ladha, J. K., \& Gathala, M. K. (2009, November). Direct drill-seeded rice: A need of the day. In Annual meeting of agronomy society of america, Pittsburgh (pp. 1-5).

37. Gardner-Outlaw, T., \& Engelman, R. (1997). Sustaining water, easing scarcity.

38. Tomita, S., Miyagawa, S., Kono, Y., Noichana, C., Inamura, T., Nagata, Y., ... \& Nawata, E. (2003). Rice yield losses by competition with weeds in rainfed paddy fields in north-east Thailand. Weed Biology and Management, 3(3), 162-171.

39. Fukai, S. (2002, January). Rice cultivar requirements for direct seeding in rainfed lowlands. In International Workshop on Direct Seeding in Asian Rice Systems'.(Eds S Pandey, M Mortimer, L Wade, TP Tuong, K Lopez, B Hardy.) pp (pp. $257-$ 270).

40. Maity, S. K., \& Mukherjee, P. K. (2008). Integrated weed management in dry direct-seeded rainy season rice (Oryza sativa). Indian Journal of Agronomy, 53(2), 116-120.

41. Joshi, E., Kumar, D., Lal, B., Nepalia, V., Gautam, P., \& Vyas, A. K. (2013). Management of direct seeded rice for enhanced resource-use efficiency. Plant Knowledge Journal, 2(3), 119.

42. Shah, M.L., \& Bhurer, K.P. (2005). Response of wet seeded rice varieties to sowing dates. Nepal Agric Res J., 6: 35-38.

43. Devkota, K., Sudhir-Yadav., Ranjit, J.D., Sherchan, D.P., Regmi, A., Devkota, M., Akhtar, T., Humphreys, E., Chauhan, B.S., Kumar, V., McDonald, A.J., \& Malik, R.K. (2013). Guidelines for Dry seeded rice (DSR) in the terai and mid-hills of Nepal. CSISA and IFAD joint publication. IRRI and CIMMYT, 40.

Cite This Article: Razan Malla (2021). Direct-Seeded Rice in Nepal. East African Scholars J Agri Life Sci, 4(3), 75-81. 